\title{
Ich bin MS-krank, also denke ich, dass...
}

Charlotte Hurni

- wer keine Energie, auch keine Zeit hat -

\section{- Inkontinenz einsam oder treu machen kann -}

- ich mich vergewissere bis zur Gewissheit, dass es keine gibt -

- ich mich betrogen fühle, wenn Gesundheit das höchste Gut ist -

- (Selbst)Mitleid das schlimmste Leid ist -

- Bücher gute Freunde sind -

- ich keinen Trost brauche, aber Kraft, um die anderen zu trösten -
- es mit Schmerzen keine Selbstvergessenheit gibt -

- sich das Selbstverständliche nicht mehr von selbst erklärt -

- ich leide, also nicht mehr sein will -

- der Schlaf mehr Flucht als Erholung ist -

\section{- Freunde es wert sind, für sie zu leben -}

- man lebendig tot ist, wenn man keinen Sinn für die Sinne mehr hat -

- manchmal nur der Mund und nicht mehr die Augen lachen -

\section{- man Leute ausreden lassen soll,} die nichts mehr zu sagen haben -

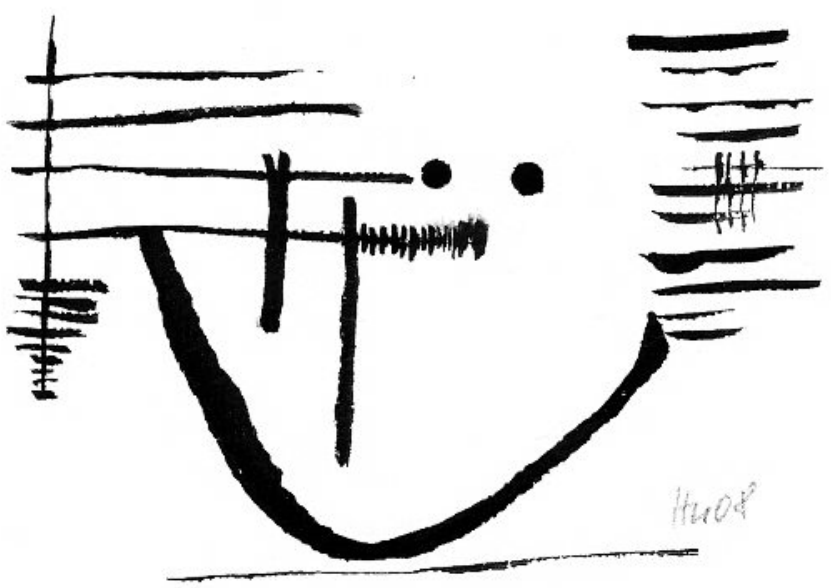

- Krankheit Kreativität fördert, doch niemand dafür krank wird -

\section{- für Kranke und Geschwächte der Spass manchmal beim Spass aufhört -}

- Vergesslichkeit den Vorteil hat, dass man endlich vergessen kann -
- alles, was nicht umbringt, zum Weiterleben zwingt -

- ich nicht weiss, ob Emotionen oder Vernunft wichtiger sind -

- man in einer Leistungsgesellschaft vorbildlich krank sein sollte -
Korrespondenz: Charlotte Hurni Forchstrasse 251 CH-8032 Zürich

charlotte.hurni@bluewin.ch
- Behinderte dann integriert sind, wenn sich auch Nichtbehinderte über sie lustig machen dürfen -

- ich manchmal von Ratschlägen erschlagen werde -

- der Müssiggang müssig wird -

- Schulden besser sind als ein Krankheitsgewinn -

- ich für mein Kranksein nicht bewundert werden will - 